\title{
A Comprehensive Method to Isolate High Quality DNA from the Cultivars of Hibiscus
}

\author{
Jayarama Reddy \\ St. Joseph's Post Graduate and Research Centre, 36, Langford Road, \\ Bangalore- 560027. INDIA.drjayaramreddy@gmail.com
}

\begin{abstract}
An attempt was made to develop the best method to extract DNA from four selected varieties of the ornamental and medicinal plant, Hibiscus rosa-sinensis which can be distinguished one from the other morphologically. DNA extraction was carried out in several sets and each time there were more modifications that have been documented to bring out an efficient method to extract DNA from this plant of the Mavlacea family, which have a high content of gummy, mucilaginous substances. That apart, the DNA extracted was qualified and quantified based on the Beer-Lambert's law using UV-Visible Spectrophotometer. The results were not up to the mark of purity but further modifications can be made in this respect. Then a comprehensive protocol to isolate the DNA from Hibiscus sp was developed. The plant genomic DNA was extracted and also restriction digested by several combinations of restriction enzymes and conditions of incubation. The best one was found to completely digest the genomic DNA and this was the combination of three restriction enzymes Eco RI, Bam HI, Hind III at 37을 for 15-18 hours. The dual success in developing a standardized condition for restriction digestion of genomic DNA from this species as well as the obtaining of completely digested plant genomic DNA can be further used in DNA Analysis of the related cultivars, and their RAPD analysis can be carried out which helps to identify and characterise the plants within this species as part of germplasm conservation.
\end{abstract}

Keywords: Hibiscus rosasinensis, Plant genomic DNA, Restriction digestion and RAPD analysis

\section{INTRODUCTION}

Isolation of plant genomic DNA is the requirement for most genome characterization and mapping and isolation of genes for genetic engineering. The degree of purity and quality of DNA obtained varies from application to application. A good extraction protocol should yield DNA reasonably pure and intact. Yield should be adequate, less time consuming, simple and cost effective. DNA extraction by far is a major bottleneck in practical marker assisted selection (MAS) analysis of DNA because it is time consuming, labour intensive and thereby increases costs [12]. Numerous methods for DNA isolation from plant materials are available. Methods may be based on use of detergents like SDS (Sodium Dodecyl Sulphate), non-ionic detergents like CTAB, other methods include use of $\mathrm{CsCl}_{2}$ gradients, Rapid and High salt extraction [1] which can be used to liberate and complex with total cellular nucleic acids (nuclear, chloroplasts and mitochondrial DNA) from a wide array of plant genera and tissue types. In the case of plant DNA extraction low temperature is generally preferred. Different parts of plant are used such as leaves, flowers, shoot tips, leaf disc [7]. DNA extraction from several plant species have been carried out by many researchers in order to obtain optimal results in the analysis of DNA. For example DNA has been successfully extracted from $A$. thaliana [15]. A modified method for DNA extraction in plants has been introduced at $1990^{[5]}$. Similarly so many works had been carried out for developing methods in DNA extraction in plants $[4,8,13,19,20]$. All the different methods available for isolation of DNA accomplish the following: the cell wall is broken or digested to release the cellular contents. This is usually done by grinding the tissue in liquid nitrogen with mortar and pestle. The cell membranes must be disrupted so that the DNA is released into the extraction buffer. This is accomplished by using a detergent like SDS (Sodium Dodecyl Sulphate) or CTAB. The DNA must be protected from endogenous nucleases. For this purpose, EDTA is used as a chelating agent that binds magnesium ions that act as a co- factor for most of the nucleases. The tissue buffer mixtures emulsified with chloroform-phenol denature and separate the proteins from DNA enabling DNA to be precipitated with either ethanol or Isopropanol. Shearing of DNA should be minimized. Preparation of high molecular weight DNA with minimum amount of shearing and non-specific damage and whose size range is $100 \mathrm{~kb}$ is adequate for the production of genomic libraries. The size of large molecular weight DNA can be checked by pulsed field gel electrophoresis. DNA preparation can be made RNA free by digestion with riboucleases. Proper choice of the leaf tissue is very important for DNA extraction. The use of very young leaf tissues has resulted in poor yields. We found that partially expanded leaves are the best material. The best results were obtained from rapidly expanding leaves, one to two nodes from the shoot tip ${ }^{[14]}$. With fully expanded leaves the yield was low and the DNA was not completely digestible. However, we were able to get equally good results with fully expanded leaves when PVP (Polyvinylpyrrolidone) was added to the extraction buffer. PVP has been used to remove 
polyphenols from mature, damaged and improperly stored leaf tissues $[5,11,18]$. PVP forms complex hydrogen bonds with polyphenolic compounds which can be separated from DNA by centrifugation [13]. The presence of polyphenolic compounds can be reduced by keeping plant material frozen before extraction and by using PVP in the DNA extraction procedure. The developmental stage of the plant is also important. The optimal time for leaf collection was during the period of active shoot elongation following bud break. Later in the season DNA extraction was difficult and the DNA obtained was unstable for long term storage. The modified procedure based on CTAR is used for DNA extraction[6]. $\quad \mathrm{NaCl}$ has been used to remove polysaccharides ${ }^{[8]}$ and PVP to purge polyphenols ${ }^{[13]}$. This procedure does not involve $\mathrm{CsCl}$ density gradient purification steps. PVP removes polyphenols and other resinous materials that make DNA unrestrictable in a R.E. digestion mixture and unamplifiable in PCR. The use of CTAB as a detergent in the extraction buffer disrupts the cell membrane and releases the cell contents. CTAB is a cationic detergent which aids in the lysis of cell membrane and will form complexes with nucleic acids. Sodium chloride aids in the formation of nucleic acid CTAB complex and is at best used when it is warm. Addition of $0.2 \% 2$-mercaptoethanol just before use of extraction buffer is recommended for best effect of the extraction buffer. EDTA chelates the magnesium ions which is an essential co factor for the enzyme to act and prevent the indigenous endonulcease to act on the nucleic acids. $1 \mathrm{M} \mathrm{NaCl}$ facilitates the removal of polysaccharides by increasing their solubility in ethanol so that they do not co-precipitate with DNA. DNA yields from Vitis species, Ampelopsis and other woody perennial plant species by the above mentioned procedure range from 0.5 to $1.0 \mathrm{mg} / \mathrm{g}$ fresh leaf tissues with A260/A280 between 1.8 and 2.0. The procedure is fast and simple and 30 to 40 DNA samples may be processed in a single day. Results of DNA restriction digestion with three endonucleases (EcoRI, EcoRV and HindIII) showed complete digestion. It is also evident that the uncut DNA exhibits little shearing and is suitable for Southern hybridization [22]. The DNA is also amplifiable in PCR using the RAPD technique [24]. Complete digestion with restriction endonucleases and amplification in PCR indicate the absence of polysaccharides. Polysaccharides are difficult to separate from DNA [16]. These compounds are easily identifiable in the DNA preparations as they impart a sticky, viscous consistency to the DNA preparations dissolved in TE buffer. Polysaccharides interfere with several biological enzymes such as polymerases, ligases and restriction endonucleases $[17,21]$. It has

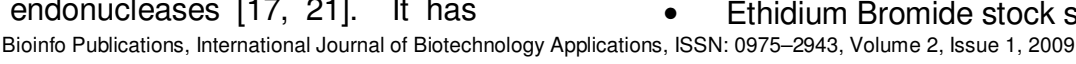

been found that when polysaccharides were not removed the DNA would not amplify. PCR amplification of the DNA with several ten base long oligonucleotides and complete DNA restriction results are consistent with these results. DNA amplification was possible due to the absence of contaminants [8,23]. $1 \mathrm{M} \mathrm{NaCl}$ facilitated the removal of polysaccharides by increasing their solubility in ethanol so that they did not co-precipitate with the DNA [8]. However, higher concentrations of $\mathrm{NaCl}$ (more than $2.5 \mathrm{M}$ ) were more effective with the some of the species that were under study. The simplicity of the procedure makes it very practical for DNA extraction especially from Vitis species, hybrids and Ampelopsis and generally from other plant species such as apple, apricot, peach, plum and raspberry. Moreover, DNA yield is higher compared with other procedures used for DNA extraction from grapevines [3].

\section{MATERIALS AND METHODS}

Selection of Plant material

Four varieties of Hibiscus rosa-sinensis were collected from Lalbagh Botanical Gardens, Bangalore. The flowers were identified and characterized after comparison with Hibiscus rosa-sinensis cultivars ${ }^{[10]}$. The plants were then grown in the green house under suitable conditions and transferred to various locations, one of them being the college campus from where it was sampled for the experimentation given below.

The following plants were selected.

A. Pink flowers Hibiscus rosa-sinensis 'Laffrans' (fig1.1)

B. Red crumpled flowers Hibiscus rosasinensis 'Juno' (double-whorled) double rose of China (fig1.2)

C. Red single-whorled flowers Hibiscus rosa-sinensis (fig1.3)

D. White flowers Hibiscus rosa-sinensis (fig 1.4)

\section{Collection of plant material}

Tender fresh leaves were collected and carefully cut into pieces avoiding the midrib and approximately $1.5 \mathrm{~g}$ of sample was weighed carefully. It was washed using double distilled water followed by alcohol. The leaves were then pat dried and wrapped in parafilm wrap and kept in the freezer 2 days prior to the experiment. In another set of experimentation fresh tender leaves which were unexposed to sunlight were collected in the morning by 9.00am and treated as above but used directly instead of freezing.

\section{Preparation of Stock Solution}

A modified method was used for preparation of stock solution[20] (See Appendix-I)

Materials required

- 5 M EDTA pH 7.2

Ethidium Bromide stock solution.
ISSN: 0975-2943, Volume 2, Issue 1, 2009 
- 6X Gel Loading Buffer(100ml)

- $\quad 0.1 \mathrm{~N} \mathrm{HCl}$

- Lysis buffer/ CTAB Extraction Buffer

- $\quad 5 \mathrm{~N} \mathrm{NaCl}$

- $\quad 0.1 \mathrm{~N} \mathrm{NaOH}(100.0 \mathrm{ml})$

- Saturated Phenol

- 1X TAE Buffer(350ml)

- Tris EDTA (TE) Buffer pH 8.0(100ml)

- $1 \mathrm{M}$ Tris $\mathrm{HCl} \mathrm{pH}-7.8$

- $\quad 3$ M Sodium acetate buffer $\mathrm{pH} 5.5$

- Chloroform: Isoamyl alcohol (freshly prepared)

- Phenol:Chloroform(1:1)

- $5.0 \mathrm{ml}$ of Phenol is mixed with $5.0 \mathrm{ml}$ of chloroform.

- DNA standard solution (30mg\%)

Isolation of plant genomic DNA

- The leaves treated as above were crushed using a mortar and pestle. In another set of experiments using the same samples, along with leaves $0.5 \mathrm{~g}$ of PVP (Polyvinylpyrrolidone) was crushed using a pestle and mortar.

- $\quad$ CTAB extraction buffer was pre-heated $65^{\circ} \mathrm{C}$ in water bath and $0.2 \%$ 2mercaptoethanol was added just before use of extraction buffer. $8.0 \mathrm{ml}$ of this solution was added to the ground paste and transferred to a $30.0 \mathrm{ml}$ tube. The mortar and pestle was rinsed by addition of $2.0 \mathrm{ml}$ of the CTAB buffer and mixed with the original extract.

- The leaf slurry was mixed several times by gentle inversion and incubated for 60 minutes in a water bath at $65^{\circ} \mathrm{C}$ and swirled regularly to ensure efficient extraction ${ }^{[2]}$.

- The tubes were removed from the water bath allowed to cool down for 4$5 \mathrm{~min}$. After this $5.0 \mathrm{ml}$ Chloroform: Isoamyl alcohol (24:1) was added and gently mixed for 5-10mins to form an emulsion. The mixture was transferred to $1.5 \mathrm{ml}$ Eppendorf tubes/ alternatively $10 \mathrm{ml}$ plastic tubes can also be used, using a $2000 \mu \mathrm{l}$ micro tip pipette, and it was spin in a centrifuge for $10 \mathrm{mins}$ at $4300 \mathrm{~g}(8000 \mathrm{rpm})$ at room temperature to separate the phases.

- The top aqueous phase is poured out into new $15.0 \mathrm{ml}$ tube and the centrifugation is repeated with $5.0 \mathrm{ml}$ Chloroform: Isoamyl alcohol (24:1) once or twice till almost clear aqueous phase is obtained.

- To this clear aqueous phase obtained, $6.0 \mathrm{ml}$ of cold Isopropanol (2- Propanol) was added. Mix by gentle inversion to precipitate the nucleic acid.
- In one of the plant species, sample B, it was incubated overnight at $24^{\circ} \mathrm{C}$ (room temperature) to allow DNA precipitation. The DNA was then scooped out using a glass hook/rod or the solution was carefully poured out retaining the DNA in the tube which is pat dried with tissue paper.

- The pellet was dissolved in $500-1000 \mu \mathrm{l}$ TE Buffer followed by addition of $1.0 \mathrm{ml}$ Phenol: Chloroform (1:1) mixed thoroughly and spin at $4500 \mathrm{~g}$ to separate the phases and remove the aqueous phase to a new $10 . \mathrm{ml}$ test tube. Into this $1.0 \mathrm{ml}$ Chloroform: Isoamyl alcohol (24:1) was added, Mixed thoroughly and spin at $4500 \mathrm{~g}$ to separate the phases and remove the aqueous phase to a fresh clean test tube.

- To the aqueous phase, $50 \mu \mathrm{l} 3 \mathrm{M}$ sodium acetate buffer pH5.5 and $2.5 \mathrm{ml}$ absolute ethanol was added to precipitate the DNA. The tubes were inverted 1015times and incubate at $-20^{\circ} \mathrm{C}$ for 20 mins even up to 1 hour for sample $B$.

- The DNA precipitate obtained is washed with $70 \%\left(0-4^{\circ} \mathrm{C}\right)$ cold ethanol, decanted and completely air dried. The pellet is dissolved in about 250-800 $\mu$ l of TE buffer.DNA at $-20^{\circ} \mathrm{C}$ for short term storage ${ }^{[9]}$.

- Quantify DNA in a spectrophotometer at A260. Prepare the restriction digestion mixture for genomic DNA restriction digestion.

Note: For better result the entire extraction procedure was repeated for several times.

DNA purity Analysis by Spectrophotometre

The Spectrophotometric Analysis is also of significant interest and gives an idea about the purity and quantity of DNA extracted and efficiency of the procedure developed.

\section{Restriction Digestion of DNA}

The restriction digestion mixture is prepared as follows and is kept for incubation for $3-4$ hrs at $37^{\circ} \mathrm{C}, 5.0 \mu \mathrm{l}$ of DNA from all samples was used.

To make a total volume of $20 \mu \mathrm{l}$ of the restriction digestion mixture finally using distilled water. In another set of $R E$ digestion, the restriction digestion mixture is prepared as follows and is kept for incubation overnight, $\sim 15$ hours at $37^{\circ} \mathrm{C}$. $20 \mu \mathrm{l}$ of DNA from all samples was used.

To make a total volume of $35 \mu \mathrm{l}$ of the restriction digestion mixture using double distilled water.

Agarose Gel Electrophoresis

Agarose gel electrophoresis was carried out for testing the restricted plant genomic DNA. The presence of Ethidium bromide in the gel facilitates the clear observation of DNA in the gel. 
The technique of Submarine gel electrophoresis was used.

Procedure:

- Prepare sufficient amount of electrophrosis buffer to fill the electrophorosis tank and to prepare the gel.

- Add agarose to the TAE buffer based on the \% of agarose and amount of TAE buffer. Stock solution of Ethidium bromide is prepared by dissolving 10mg of Ebr in $1 \mathrm{ml}$ of water. Add $0.6 \mu \mathrm{g}$ of Ethidium bromide from stock solution per ml of TAE buffer. Place it in boiling water for heating.

- Place the gel tray in casting tray and set the comb. Pour agarose to about 5-mm thick, avoiding bubble formation.

- After the gel is completely set, carefully remove the comb. Remove the gel tray from casting tray and place it in electrophoresis tank.

- Add just enough buffers to cover the gel.

- Mix samples of DNA with the gel loading buffer $(10 \mu$ l of gel loading dye for $30 \mu$ l of DNA sample)

- Slowly load DNA samples into the wells of the submerged gel using disposable micropipette.

- Marker DNA of known size should be loaded on left side of the gel.

- Close the lid of the gel tank and start on the electrical potential.

- After the run, view the gel on a UV trans-illuminator.

\section{RESULT AND DISCUSSION}

A. Estimation of concentration and Purity of DNA

DNA has a maximum absorbance at about $260 \mathrm{~nm}$. Based on the extinction coefficient an optical density (O.D.) of $1.0 \mathrm{ppm}$ at $260 \mathrm{~nm}$ corresponds to approximately $50 \mu \mathrm{g} / \mathrm{ml}$ of double stranded DNA. The ratio of O.D. 260/280 provides the estimate of purity. A typically pure preparation of DNA has a ratio of approximately 1.8. A ratio less than 1.8 indicates the probable presence of proteins and/ or other UV absorbers. Thus, it is advisable to re-precipitate the DNA. A ratio higher than 2.0 indicates that the sample may be contaminated with chloroform or phenol and should be re-precipitated with ethanol. The results obtained in the purity analysis of DNA indicate that the sample is not very pure however the sample $\mathrm{C}$ is the best of the lot. Further modifications can be added and this aspect can be improved. In terms of concentration the best
DNA extraction was found to be in the sample C and also in sample A consistently, the most probable reason being that the type of flowers in sample $A$ and $C$ do not seem to have interfering substances which otherwise would make the UVSpectrophotometric analysis unclear. Apart from this, flowers in Sample $A$ and $D$ are single whorled while those in the samples $B$ and $D$ have double/multiple whorls. By carrying out Soxellete extraction, we can isolate and study the various pigments and components in the plant extract and further a TLC (Thin Layer Chromatography) was able to identify the pigments even better.

B. Analysis of restricted genomic DNA by using Agarose Gel Electrophoresis

The extracted DNA was Restriction digested and suitable conditions for the same were set up. An $\mathrm{RE}$ digestion mixture was prepared using one restriction enzyme, Eco $\mathrm{RI}$ for one hour, at $37^{\circ} \mathrm{C}$. The results were not encouraging, however, restricting the DNA for 4 hours, at $37^{\circ} \mathrm{C}$ using two enzymes, EcoRI and Bam HI in the next attempt resulted in some amount of DNA digestion. Then finally successful results were obtained with the use of the above mentioned RE along with HindlII and overnight incubation for almost 15 hours, at $37^{\circ} \mathrm{C}$. Agarose gel electrophoresis was carried out for testing the restricted plant genomic DNA. The presence of Ethidium bromide in the gel facilitates the clear observation of DNA in the gel. The presence or absence of DNA bands indicates the efficiency of restriction digestion with RE used. It was found that the plant genomic DNA from all the four samples gave clear distinguished bands that were observed under UV Lamp due to presence of Ethidium bromide. The restriction digestion for set I was incomplete and the bands were not clear nor were they countable. In Sample set II the samples A and D gave very clear bands in agarose gel electrophoresis which was carried out using Ethidium bromide as fluorescent dye. Samples B and $C$ did not give very clear bands but were a smeared set of bands. This showed that there was DNA restriction but not as well as the samples $A$ and $D$. The conclusions that could be drawn from this are as follows: it is likely that the research done so far can be carried forward by optimizing the restriction digestion mixture for the cultivars of Hibiscus sp. It may be used further in different aspects of research on medicinal uses of the plant.

\section{SUMMARY}

The isolation and extraction of DNA from Hibiscus rosasinensis cultivars was carried out and the objectives were fulfilled as expected. An attempt was made to develop the best method to extract DNA from four selected Hibiscus rosasinensis which can be distinguished one 
from the other morphologically. The extraction was carried out by a modification of Doyle and Doyles method $^{[6]}$ and using detergent CTAB as the primary component in the Extraction buffer ${ }^{[20]}$. DNA extraction was carried out in several sets and each time there were more modifications that have been documented to bring out an efficient method to extract DNA from this plant of the Mavlacea family, which have a high content of gummy, mucilaginous substances. The DNA extracted was qualified and quantified based on the Beer-Lambert's law using UV- Visible Spectrophotometer. The results were not up to the mark of purity but further modifications can be made in this respect. Then a comprehensive protocol to isolate the DNA from Hibiscus sp was developed.

The plant genomic DNA was extracted and also restriction digested by several combinations of restriction enzymes and conditions of incubation. The best one was found to completely digest the genomic DNA and this was the combination of three restriction enzymes Eco $\mathrm{RI}$, Bam $\mathrm{HI}$, Hind III at $37^{\circ} \mathrm{C}$ for $15-18$ hours. Endonucleases for the restriction of plant genomic DNA was identified. Methods of DNA analysis in Hibiscus are developed and studied. The dual success in developing a standardized condition for restriction digestion of genomic DNA from this species as well as the obtaining of completely digested plant genomic DNA can be further used in DNA Analysis of the related cultivars, and their RAPD analysis can be carried out which helps to identify and characterise the plants within this species as part of germplasm conservation. The DNAs from the different cultivars of Hibiscus sps can be compared. This is gaining importance as many plants are nearing extinction and the various methods of plant conservation are being discussed in the light of global warming. Thus the objectives were successfully fulfilled and using this information a booklet for easy access to standardized protocol for DNA isolation to researchers in Hibiscus can be prepared.

\section{REFERENCES}

1. Aljanabi and Martinez, 1997. Universal and rapid salt-extraction of high quality genomic DNA for PCR- based techniques, Nucleic Acids Res. November 15; 25(22): 4692-4693.

2. Ausubel F.M., et al., 2002. Short Protocols in Molecular Biology. 5th Edition. John Wiley \& Sons Publications. 2.4: 2-10

3. Bourquin, J.-C., L. Otten and B. Walter. 1991. Identification of grapevine rootstocks by RFLP. C.R. Acad. Sci. Paris 312 Série III:593-598.

4. Dellaporta SL, Wood J, Hicks JB (1983). A plant DNA mini preparation: Version II, Plant Mol. Bio. Rep. 1(1): 19-21. Bioinfo Publications, International Journal of Biotechnology Applications, ISSN: 0975-2943, Volume 2, Issue 1, 2009
5. Doyle, J.J. and J.L. Doyle. 1987. A rapid DNA isolation procedure from small quantities of fresh leaf tissues. Phytochem Bull. 19:11-15.

6. Doyle, J.J. and J.L. Doyle. 1990. Isolation of plant DNA from fresh tissue. Focus 12:13-15.

7. Edwards K, Johnstone C, Thompson C (1991). A simple and rapid method for the preparation of plant genomic DNA for PCR analysis. Nucleic Acid Res. 19: 1349.

8. Fang, G., S. Hammar and R. Rebecca. 1992. A quick and inexpensive method for removing polysaccharides from plant genomic DNA. BioTechniques 13:52-56.

9. Foolad M.R. et.al.1995. Molecular Biotechnology: Principles and Practises. Wiley Publications. U.S.A. 286.

10. Graf, A.B.1992. Tropica: Color Cyclopedia of Exotic Plants and Trees from the Tropics and Subtropics for Warm-Region Horticulture, in Cool Climate the Sheltered Indoors. Roehrs \& Co. Publishers.9th Ed: 1012-14, 625630.

11. Howland, D.E., R.P. Oliver and A.J. Davy. 1991. A method of extraction of DNA from birch. Plant Mol. Biol. Rep. 9:340-344.

12. Ki J.S. et. al.2007. A protocol for Direct DNA isolation from solid biological sources without pretreatments with proteinase- $K$ and/or homogenization through automated DNA extraction. Journal of Bioscience Bioengineering. 103(3):242-6.4366-3

13. Maliyakal, E.J. 1992. An efficient method for isolation of RNA and DNA from plants containing polyphenolics. Nucleic Acids Res. 20:2381.

14. Mauro, M.-C., M. Strefeler, N.F. Weeden and B.I. Reisch. 1992. Genetic analysis of restriction fragment length polymorphisms in Vitis. J. Hered. 83:1821.

15. Meyerowitz et. al. ( 1987ish) Plant DNA Extraction

16. Murray, M.G. and W.F. Thompson. 1980. Rapid isolation of high molecular weight DNA. Nucleic Acids Res. 8:43214325.

17. Richards, E. 1988. Preparation of genomic DNA from plant tissue. In: Current Protocols in Molecular Biology. (eds. F.M. Ausubel, R.E. Kingston, D.D. Moore, J.A. Smith, J.G. Seidman and K. Struhl), pp. 2.3.2-2.3.3. Greene Publishing Associates and Wiley-Interscience, New York.

18. Rogers, S.O. and A.J. Bendich. 1985. Extraction of DNA from milligram 
amounts of fresh, herbarium and mummified plant tissues. Plant Mol. Biol. 5:69-76.

19. Rowland, L.J. and B. Nguyen. 1993. Use of polyethylene glycol for purification of DNA from leaf tissue of woody plants. BioTechniques 14: 734736.

20. Saghai-Maroof MA, Soliman KM, Jorgensen RA, \& Allard RW (1984) Fungal DNA Isolation, PNAS 81:80148018

21. Shioda, M. and K. Marakami-Muofushi. 1987. Selective inhibition of DNA polymerase by a polysaccharide purified from slime of Physarum polycephalum. Biochem. Biophys. Res. Commun. 146:61-66.

22. Southern, E.M. 1975. Detection of specific sequences among DNA fragments separated by gel electrophoresis. J. Mol. Biol. 98:503517.

23. Webb, D.M. and S.J. Knapp. 1990. DNA extraction from a previously recalcitrant plant genus. Plant Mol. Biol. Rep. 8:180185.

24. Williams, J.G.K., A.R. Kubelik, K.J. Livak, J.A. Rafalski and S.V. Tingey. 1990. DNA polymorphisms amplified by arbitrary primers are useful as genetic markers. Nucleic Acids Res. 18:65316535.

\section{APPENDIX-I}

\section{A. Lysis buffer/ CTAB Extraction Buffer}

$5.0 \mathrm{ml}$ of $1 \mathrm{M}$ Tris- $\mathrm{Cl}$ is added to $5.0 \mathrm{ml}$ of $0.5 \mathrm{M}$ EDTA, to this $7.0 \mathrm{ml}$ of $5 \mathrm{~N} \mathrm{NaCl}$ was added. It is warmed in a water bath to $65^{\circ} \mathrm{C}$ and $0.5 \mathrm{~g}$ of CTAB is added followed by proper mixing and finally just before use, $250 \mu$ l of $\beta$ mercaptoethanol was added. The volume of the lysis buffer was made upto $50.0 \mathrm{ml}$ using distilled water and $\mathrm{pH}$ was adjusted to 7.8 using Pen $\mathrm{pH}$ meter using acid or $1 \mathrm{~N} \mathrm{NaOH}$ or $\mathrm{NaCl}$. Note: Fumes and solution of $\beta$ - Mercaptoethanol is very dangerous and one must avoid inhalation and direct skin contact. As a precaution, wear gloves while handling.

\section{B. Saturated Phenol}

On a Magnetic stirrer mix $100.0 \mathrm{ml}$ Phenol with $100.0 \mathrm{ml} 1 \mathrm{M}$ Tris for $15 \mathrm{mins}$. Two phases separate; aspirate the upper phase using rubber bulb pipette. Repeat the mixing with equal volume of $0.1 \mathrm{M}$ Tris $(\mathrm{pH} 7.5)$ twice or thrice till phenol is concentrated. Store and use carefully.

\section{TAE Buffer(50X)}

$2.42 \mathrm{~g}$ of $2 \mathrm{M}$ Tris is weighed, to it $1.86 \mathrm{~g}$ of $5 \mathrm{M}$ EDTA is added. $5.71 \mathrm{ml}$ of Glacial Aceteic acid is added and remaining volume is made up by adding distilled water. The $\mathrm{pH}$ is adjusted to 8.0. To prepare 1X TAE buffer add $7.0 \mathrm{ml}$ of $50 \mathrm{X}$ TAE Buffer to $343 \mathrm{ml}$ of Distilled water. Adjust $\mathrm{pH}$ to 8.0.

\section{3 M Sodium acetate buffer pH 5.5}

Dissolve $4.081 \mathrm{~g}$ sodium acetate $3 \mathrm{HO}$ in $6.0 \mathrm{ml}$ water. Adjust $\mathrm{pH}$ to 5.5 with glacial acetic acid and then make up the volume to $10.0 \mathrm{ml}$ sterile filter it.

\section{E. DNA standard solution (30mg\%)}

$0.3 \mathrm{mg}$ of DNA extra pure was weighed using an automatic balance and diluted in $1.0 \mathrm{ml}$ of $\mathrm{TE}$ Buffer to get final concentration of $30 \mathrm{mg} \%$. Finally from this a $1: 1$ dilution is made to get $15 \mathrm{mg} \%$ final concentration which can be used for UV-Spectrophotometer standard. 
Samples of Hibiscus rosa-sinensis

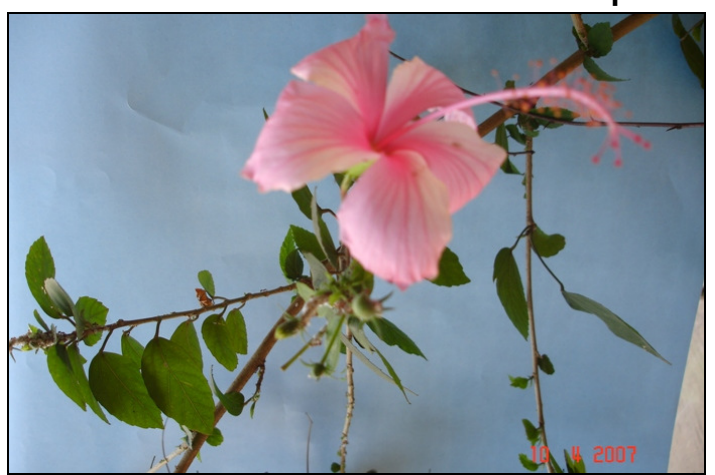

Figure 1.1: Sample A

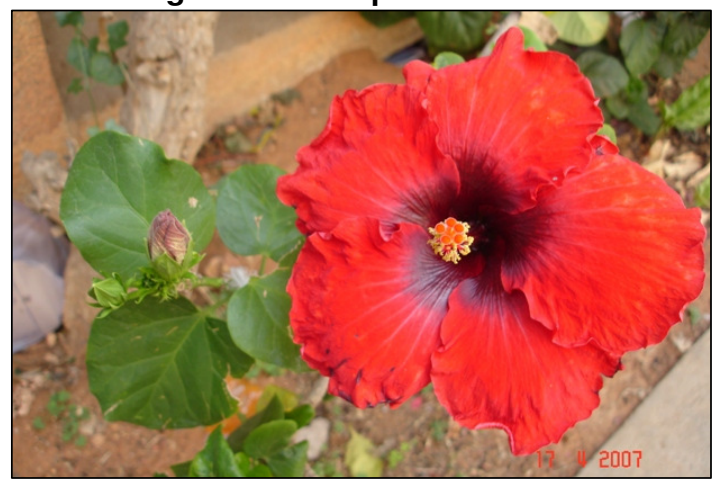

Figure 1.3: Sample C

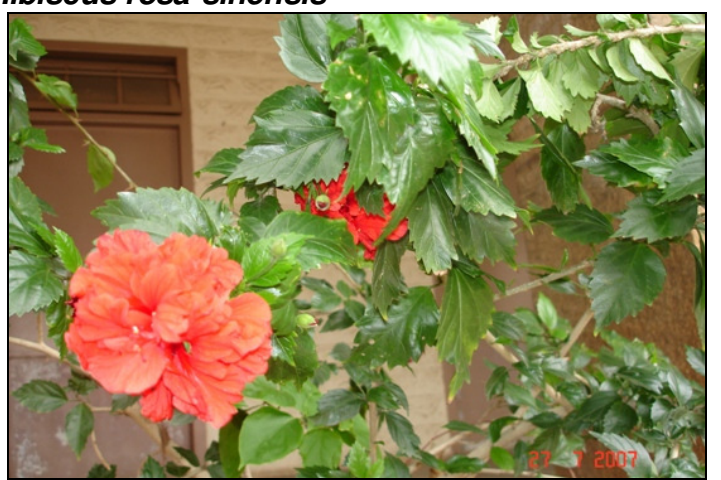

Figure 1.2: Sample B

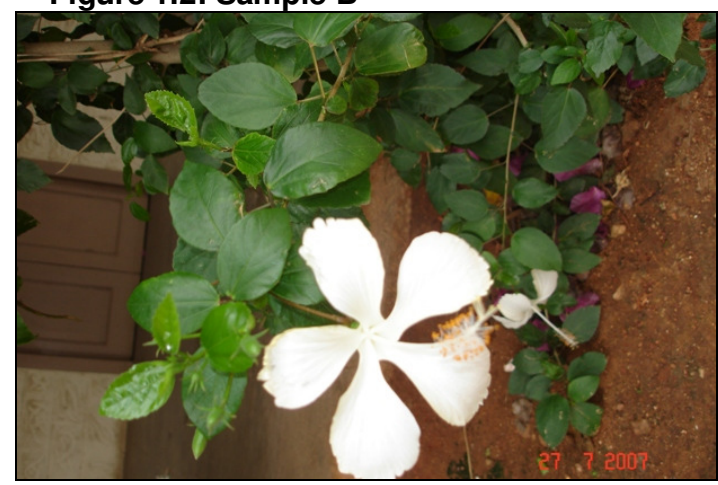

Figure 1.4: Sample D

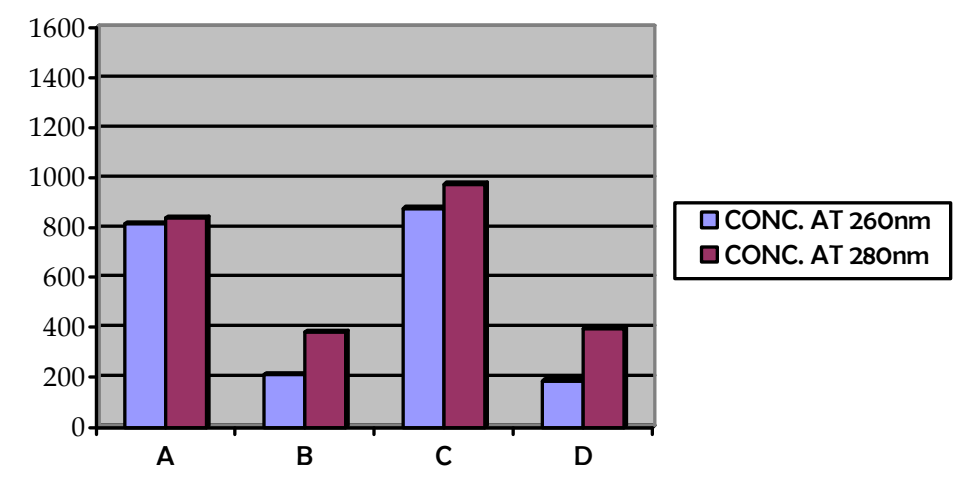

Figure 1.4 Concentration of DNA in ppm for Set I

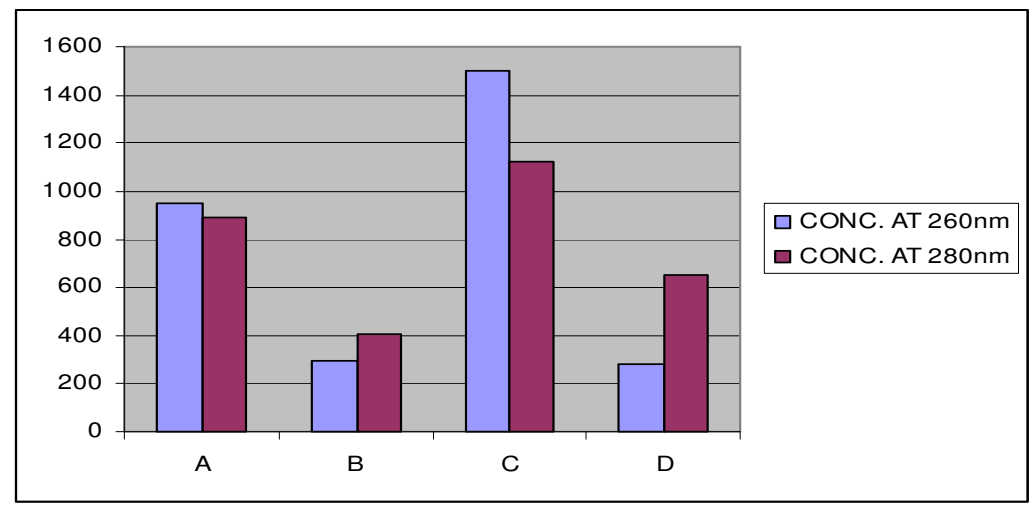

Figure 1.5 Concentration of DNA in ppm for Set II 


\section{Purity=O.D AT 260/O.D AT 280}

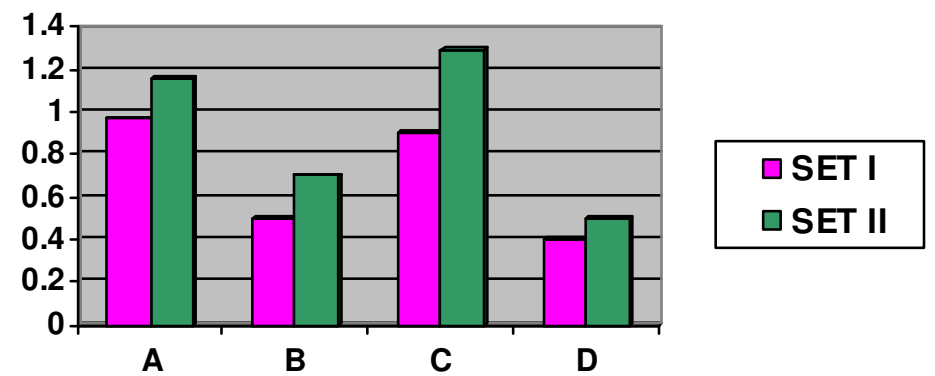

Figure 1.6 Purity of DNA in Set I and Set II
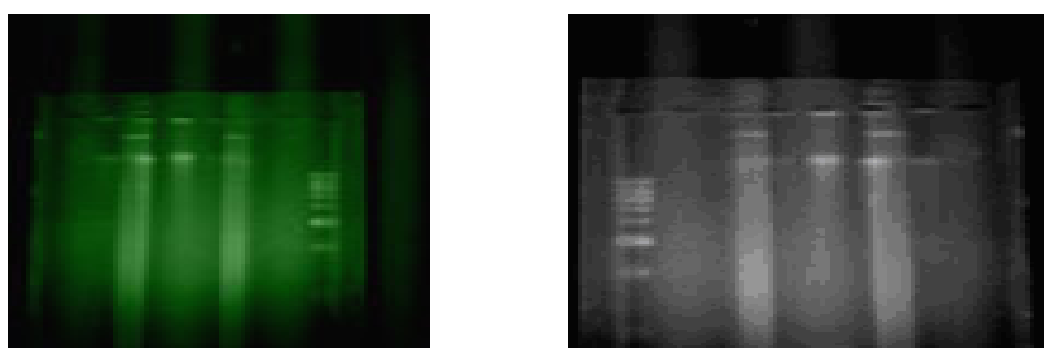

Figure 1.7 Restricted DNA of Set I; after 2 hours
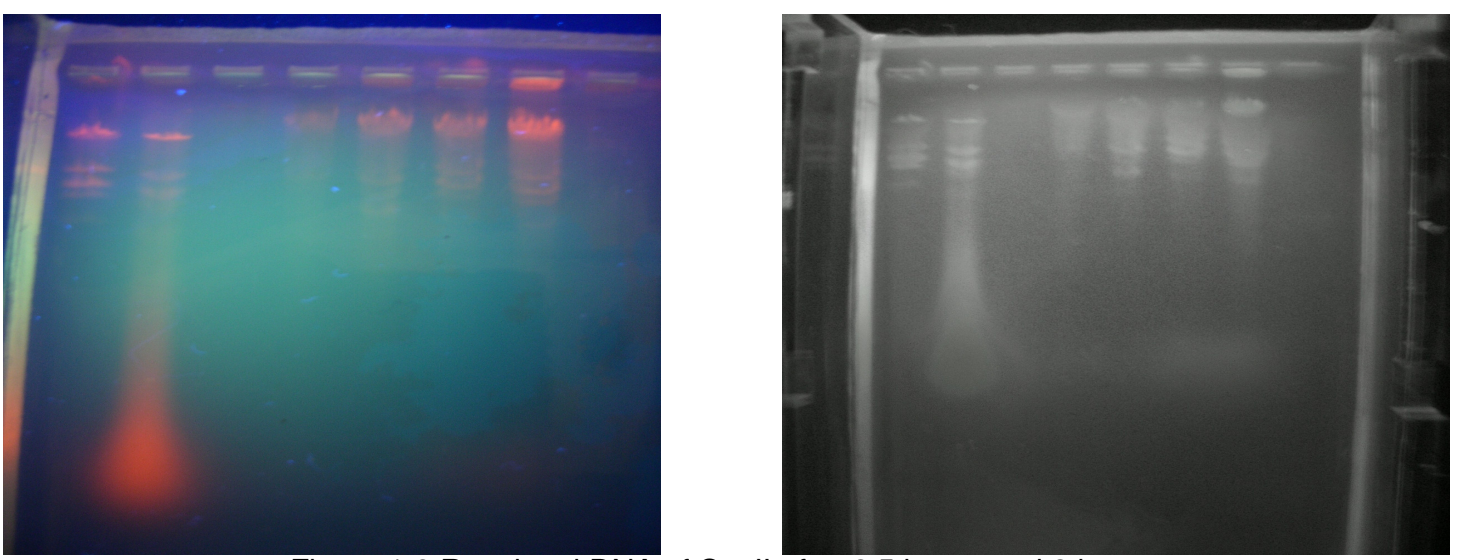

Figure 1.8 Restricted DNA of Set II after 2.5 hours and 3 hours

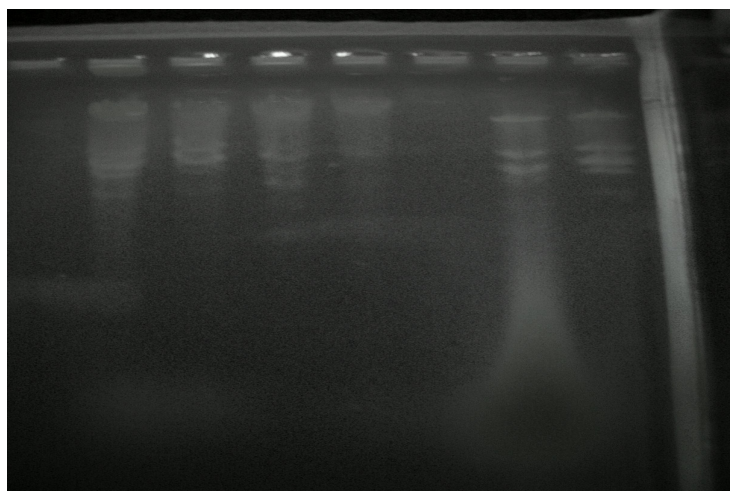

Figure 1.9 Restricted DNA of Set II after 3.5 hours

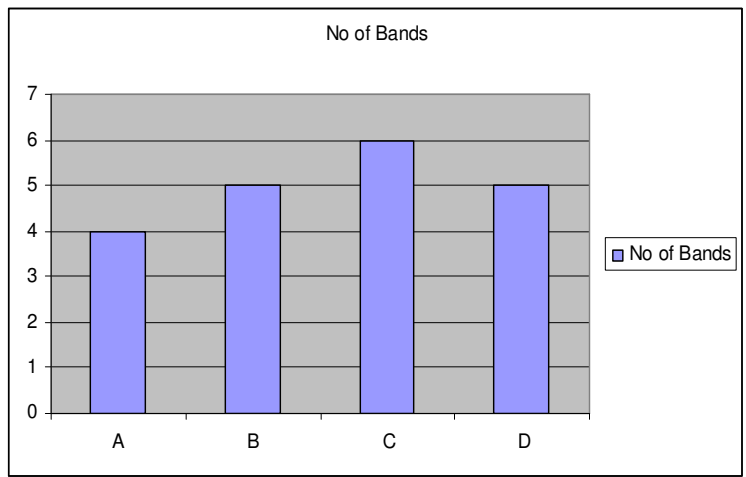

Figure 1.10 Number of DNA bands obtained at Set II 
Table 1.1 Restriction digestion mixture set I

\begin{tabular}{|l|c|c|c|}
\hline Sample & Assay Buffer $(\mu \mathrm{l})$ & EcoRI $(\boldsymbol{\mu l})$ & BamHI $(\mu \mathrm{l})$ \\
\hline Sample A & 2.0 & 1.0 & 1.0 \\
\hline Sample B & 2.0 & 1.0 & 1.0 \\
\hline Sample C & 2.0 & 1.0 & 1.0 \\
\hline Sample D & 2.0 & 1.0 & 1.0 \\
\hline
\end{tabular}

Table 1.2 Restriction digestion mixture set II

\begin{tabular}{|l|c|c|c|c|}
\hline Sample & Assay Buffer $(\boldsymbol{\mu l})$ & Hind III $(\mu \mathrm{l})$ & EcoRI $(\boldsymbol{\mu l})$ & BamHI $(\boldsymbol{\mu l})$ \\
\hline Sample A & 7.0 & 2.0 & 3.0 & 3.0 \\
\hline Sample B & 7.0 & 2.0 & 3.0 & 3.0 \\
\hline Sample C & 7.0 & 2.0 & 3.0 & 3.0 \\
\hline Sample D & 7.0 & 2.0 & 3.0 & 3.0 \\
\hline
\end{tabular}

Table 1.3 Estimation for DNA purity for SET I

\begin{tabular}{|l|c|c|c|}
\hline SAMPLE & CONC.AT 260nm(in ppm) & $\begin{array}{l}\text { CONC. AT } \\
\text { 280nm(in ppm) }\end{array}$ & $\begin{array}{l}\text { Purity = O.D.at 260 / } \\
\text { O.D. at 280 }\end{array}$ \\
\hline A & 816 & 840 & 0.97 \\
\hline B & 210 & 380 & 0.5 \\
\hline C & 878 & 974 & 0.9 \\
\hline D & 185 & 395 & 0.4 \\
\hline
\end{tabular}

Table 1.4 Estimation for DNA purity for SET II

\begin{tabular}{|l|c|c|c|}
\hline SAMPLE & CONC.AT 260nm(in ppm) & $\begin{array}{l}\text { CONC. AT } \\
\text { 280nm(in ppm) }\end{array}$ & $\begin{array}{l}\text { Purity = O.D.at 260 / } \\
\text { O.D. at 280 }\end{array}$ \\
\hline A & 946 & 890 & 1.16 \\
\hline B & 300 & 402 & 0.7 \\
\hline C & 1500 & 1125 & 1.3 \\
\hline D & 285 & 651 & 0.5 \\
\hline
\end{tabular}

Table 1.5 Colour and consistency of DNA pellet obtained

\begin{tabular}{|c|c|c|c|}
\hline Sample & $\begin{array}{c}\text { DNA Precipitate } \\
\text { Colour }\end{array}$ & $\begin{array}{c}\text { DNA Precipitate } \\
\text { consistency }\end{array}$ & $\begin{array}{c}\text { Volume of TE Buffer to } \\
\text { dissolve }(\boldsymbol{\mu l})\end{array}$ \\
\hline Sample A & Milky white & Cottony & $700 \mu l$ \\
\hline Sample B & Pale yellow & Thick & $700 \mu l$ \\
\hline Sample C & Pale white & Cottony & $800 \mu l$ \\
\hline Sample D & Cottony white & Thick & \multicolumn{2}{c|}{$800 \mu l$} \\
\hline
\end{tabular}

Table 1.6 Number of DNA Bands in Agarose gel electrophoresis for Set II

\begin{tabular}{|c|c|}
\hline Sample & No of Bands \\
\hline Sample A & $\mathbf{4}$ \\
\hline Sample B & $\mathbf{5}$ \\
\hline Sample C & $\mathbf{6}$ \\
\hline Sample D & $\mathbf{5}$ \\
\hline
\end{tabular}

